\title{
Effectiveness of lactic acid bacteria to increase the body resistance of common carp, Cyprinus carpio Linnaeus, 1758 against Aeromonas hydrophila
}

\author{
Efektivitas bakteri asam laktat dalam meningkatkan daya tahan tubuh ikan mas \\ Cyprinus carpio terhadap serangan bakteri Aeromonas hydrophila \\ Rosidah $^{1}$, Yuniar Mulyani ${ }^{1}$, Walim Lili ${ }^{1}$, Fittrie Mellianawaty Pratiwy ${ }^{1 \bowtie}$, \\ Afifah Shabirah ${ }^{2}$, Juli A Sinaga ${ }^{2}$ \\ ${ }^{1}$ Lecturer, Faculty of Fisheries and Marine Science Universitas Padjadjaran \\ ${ }^{2}$ Student, Faculty of Fisheries and Marine Science Universitas Padjadjaran \\ Fisheries Department, Faculty of Fisheries and Marine Science, Universitas Padjadjaran, Jl. Raya \\ Bandung-Sumedang Km. 21, Jatinangor, Kab. Sumedang, Jawa Barat, 45363, Indonesia
}

Diterima: 12 Mei 2021; Disetujui: 27 Oktober 2021

\begin{abstract}
This study aims to find out the right lactic acid bacteria (LAB) isolates to improve the common carp body's immune system against the attack of the Aeromonas hydrophila bacterium. Lactic Acid Bacteria (LAB) isolates were obtained from the organs of the common carp intestine. The study used a Completely Randomized Design consisting of four treatments and three replications. The treatment used was immersion of test fish for 24 hours in several isolates of LAB with a density of $10^{8} \mathrm{cfu} \mathrm{ml}^{-1}$, namely A: without LAB isolate (control), B: isolate CcB7, C: isolate CcB8, D: isolate CcB15. Immersion is done three times with a frequency of seven days. Parameters observed included clinical symptoms, survival rate, red and white blood cell counts. The results showed the immersion of LAB isolate CcB15, namely Lactobacillus gasseri was most effective for increasing the body's resistance to Common Carp, which was demonstrated by mild clinical symptoms and faster recovery, high fish survival rate (83.33\%), and number of cells the highest white blood count of $147,47 \times 10^{3}$ cell $\mathrm{mm}^{-3}$ (an increase in white blood cells by $38 \%$ ).
\end{abstract}

Keywords: Aeromonas hydrophila, clinical symptoms, fingerling of common carp, immunostimulant, lactic acid bacteria, survival rate.

\begin{abstract}
Abstrak
Penelitian ini bertujuan untuk menentukan isolat bakteri asam laktat (BAL) yang tepat untuk meningkatkan daya tahan tubuh ikan mas terhadap serangan bakteri Aeromonas hydrophila. Isolat Bakteri Asam Laktat (BAL) diperoleh dari organ usus ikan mas. Penelitian menggunakan Rancangan Acak Lengkap yang terdiri atas empat perlakuan dan tiga ulangan. Perlakuan yang digunakan adalah perendaman ikan uji selama 24 jam pada beberapa isolat BAL dengan kerapatan $108 \mathrm{cfu} \mathrm{ml}^{-1}$ yaitu A: isolat tanpa BAL (kontrol), B: isolat $\mathrm{CcB} 7, \mathrm{C}$ : isolat $\mathrm{CcB} 8$, D: isolat $\mathrm{CcB} 15$. Perendaman dilakukan tiga kali dengan frekuensi tujuh hari. Parameter yang diamati meliputi gejala klinis, tingkat sintasan, jumlah sel darah merah dan putih,. Hasil penelitian menunjukkan bahwa perendaman isolat BAL CcB15 yaitu Lactobacillus gasseri paling efektif untuk meningkatkan daya tahan tubuh terhadap ikan mas, yang ditunjukkan dengan gejala klinis ringan dan pemulihan lebih cepat, tingkat sintasan ikan tinggi $(83,33 \%)$ dan jumlah sel tertinggi. jumlah darah putih $147,47 \times 103 \mathrm{sel} \mathrm{mm}^{-3}$ (peningkatan sel darah putih sebesar 38\%).
\end{abstract}

Kata penting : Aeromonas hydrophila, gejala klinis, yuwana ikan mas, imunostimulan, bakteri asam laktat, sintasan.

$\triangle$ Penulis korespondensi

Alamat surel: fittrie.pratiwy@unpad.ac.id 


\section{Introduction}

Common carp (Cyprinus carpio L.) is one type of freshwater consumption fish which has significant economic value, contains omega 3 and low fatty acids so that it can be used as a source of animal protein that is relatively inexpensive to meet human nutritional needs and is safe for health because it can reduce the increase in cholesterol in the blood (Patriono et al. 2009) Another advantage of common carp is that it is quite easy to maintain. Therefore, common carp are in great demand, so the need for common carp continues to increase. According to fisheries data of West Java Province, common carp production in the last three years (2014-2016) has continued to grow, so that the total production in 2016 reached 213,536 tons (Ministry of Maritime Affairs \& Fisheries 2016)

The main problem in common carp cultivation is the occurrence of infectious bacterial diseases that result in a decrease in fish production. To overcome this problem, generally use various antimicrobial compounds such as antibiotics and other chemicals. However, the application of antibiotics during fish production can cause other problems, namely bacteria resistant to antibiotics and food safety, because antibiotics accumulate in the fish's body (Lipsitch 2001).

Aeromonas hydrophila is a pathogenic bacterium that commonly attacks freshwater fish, including common carp. This bacterium causes haemorrhagic septicemia, which is characterized by a bulging stomach, ulcus, lesions, abscesses of the skin, exophthalmia, and bleeding, especially in the gills and operculum (Kaleeswaran et al. 2011, Sahoo et al. 2011). This bacterial attack can cause a decrease in fish production up to $80 \%$ (Hardi \& Pebrianto 2012). The attack of $A$. hydrophila has a significant impact on the decline in fish production, and the use of antibiotics causes resistant bacteria and affect the health status of fish. It is necessary to seek safer alternative methods without any side effects to control the attack of A. hydrophila in common carp.

Some bacteria, including lactic acid bacteria (LAB), namely Lactobacillus spp., Bacillus spp., and Lactococcus spp., have been commonly used as a probiotic to improve fish growth (Harikrishnan et al. 2010, Geng et al. 2012). Bacillus sp. isolated from the intestines of fish from coastal areas in Japan produce antimicrobial compounds that can inhibit the growth of pathogenic microorganisms in cultivated fish (Sugita et al. 1998). The bacteria isolated from the intestines of freshwater fish (Providencia aeruginosa VSG-2) have shown potential as probiotics and antibacterial activity against $A$. hydrophila (Giri et al. 2012). Recent research shows that cellular components of Kocuria probiotics SM1 and SM2 have been shown to induce body immunity of rainbow trout against $\mathrm{Vib}$ rio anguillarum infection (Sharifuzzaman et al. 2011).

The probiotic cellular component has been used as an immunostimulant to enhance fish's innate and adaptive immune response, thus providing benefits to prevent disease attacks. Immunostimulants are a group of 
biological and synthetic compounds that can increase non-specific resistance by interacting directly with cells that activate the immune system in the fish's body (Rawung\& Manoppo 2014). Cells found in leukocytes that can activate the immune system are phagocytic cells (Abbas et al. 2010).

Some previous studies found that isolated lactic acid bacteria (LAB) from common carp intestine (Cyprinus carpio L.) have the potential as immunostimulants to prevent common carp from bacterial infection with Aeromonas hydrophila, indicated by antagonistic tests between lactic acid bacteria and fish pathogenic bacteria, and showing a high inhibition zone for $\mathrm{CcB} 7, \mathrm{CcB} 8$ and $\mathrm{CcB} 15$ isolates (Rosidah et al. 2018). The purpose of this study was to determine the best lactic acid bacteria (LAB) isolates in improving the body's immune system against the attack of the Aeromonas hydrophila bacterium.

\section{Materials and methods}

The research material used included 60 common carp with an average size of $10 \mathrm{~cm}$, lactic acid bacteria (LAB) isolates, namely $\mathrm{CcB} 7, \mathrm{CcB} 8$, and $\mathrm{CcB} 15$ isolated from common carp intestines and Aeromonas hydrophila bacteria with a density of $10^{8} \mathrm{CFU} \mathrm{mL} \mathrm{m}^{-1}$. The tools used include 12 pieces of aquarium (40x30x30) $\mathrm{cm}^{3}$, UTE digital scales, filter paper Whatman no. 42, haemocitometer, hand counter, pH meter, DO meter, autoclave, needle ose, petri dish, incubator, thermometer, spectrophotometer, and water heater.
This study used an experimental method with a completely randomized design consisting of 4 treatments and 3 replications, each treatment using 15 common carp. The treatment given was immersion of test fish in different isolates of LAB, namely A: control (without soaking the LAB isolate), $\mathrm{B}: \mathrm{CcB} 7$, C: CcB8, and D: CcB15.

\section{Inoculation of Lactic Acid Bacteria (BAL)} Isolates

$\mathrm{LAB}$ bacteria isolated from common carp intestine (isolates of $\mathrm{CcB} 7, \mathrm{CcB} 8$, and $\mathrm{CcB} 15)$ results of previous research were reproduced. Bacterial culture was carried out on de Mann Rogose and Sharpe (MRS) agar medium by inoculation. Media solutions and tools are sterilized in autoclave first. Then the media is poured on a petri dish and left to harden. Furthermore, bacterial isolates were cultured on MRS medium with a three-quadrant streak method, and then the bacteria were incubated under anaerobic conditions for 24 hours in an incubator at $37^{\circ} \mathrm{C}$. Pure colonies formed from each BAL isolate were re-cultured in MRS broth media in a valcon tube, incubated under anaerobic conditions for 24 hours in a $37^{\circ} \mathrm{C}$ incubator. The culture results of LAB isolates using Broth MRS will be turbid when compared to MRS broth control. Before being applied, LAB that has been cultured is calculated using a spectrophotometer

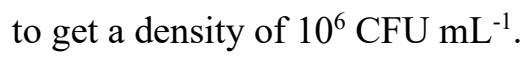




\section{Aeromonas hydrophila inoculations}

Dissolved Sodium Agar (SA) with 100 $\mathrm{ml}$ of distilled water in an Erlenmeyer flask, covered with cotton plug, heated on a hot plate with a magnetic stirrer to homogenize the solution. Sterilized the solution, used autoclave for 15 minutes at $12^{\circ} \mathrm{C}$, and poured the SA solution on Petri dish aseptically. The bacteria A. hydrophila were inoculated on the SA medium aseptically, and then incubated at $30^{\circ} \mathrm{C}$ for 48 hours. The bacteria are harvested using an ose needle, put into a test tube, and then stored at a $-20^{\circ} \mathrm{C}$ temperature. Bacterial culture is ready to use.

\section{Preparation of Aeromonas hydrophila solu-} tion

The culture of A. hydrophila was taken using an ose needle, then put into a test tube containing $10 \mathrm{ml}$ of physiological $\mathrm{NaCl}$. The test tube was covered with cotton clogs, and then the bacteria were homogenized with vortex. The homogeneous bacteria culture was put into a $2 \mathrm{ml}$ cuvette and calculated using a spectrophotometer at a wavelength of $540 \mathrm{~nm}$ and an absorbance value of 0,235 to obtain a density of $10^{8} \mathrm{CFU} \mathrm{mL} \mathrm{mL}^{-1}$.

\section{Immersion with Lactic Acid Bacteria}

The test fish used was the Majalaya strain common carp with an average length of $10 \pm$ $0.4 \mathrm{~cm}$ obtained from the Cibiru Fish Seed Center (BBI) Bandung Regency. Test fish are acclimatized for one week to adapt to the new environment and ensure the fish is in a healthy condition. A total of 12 test fishes were put into the aquarium to be soaked in LAB isolate solution $10^{6} \mathrm{CFU} \mathrm{mL}^{-1}$ according to treatment, namely A: Control (without soaking $\mathrm{LAB}$ solution); $\mathrm{B}: \mathrm{CcB} 7, \mathrm{C}$ : $\mathrm{CcB} 8$, and $\mathrm{D}$ : $\mathrm{CcB} 15$, each isolate is repeated three times. Immersion is done for 24 hours, repeated three times with a frequency of 7 days (Septiarini et al. 2012).

\section{Challenge test with Aeromonas hydrophila}

Tested fish after being treated with LAB isolates were challenged with Aeromonas hy-

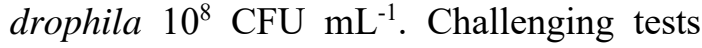
were carried out by injecting bacteria $0,1 \mathrm{~mL}$ Aeromonas hydrophila. After the fish were tested challenged to observe white and red blood cell counts; clinical symptoms included damage to the body surface, feed response, and shock and survival rate. Observations were made for seven days.

\section{Observation parameter}

Calculation of total leukocytes is done by thinning the blood with Turk's solution (ratio of 1: 10) in the mixing pipette (thoma pipette). The function of Turk's solution is to destroy red blood cells. Pipettes are then homogenized by flicking so that the blood is evenly mixed. Before the calculation is done, the solution at the end of the unmixed pipette is removed. The next droplet is inserted into the haemacytometer equipped with a cover glass and then observed under a microscope with 40 times enlargement (Rawung \& Manoppo 2014). Total leukocytes are calculated using a formula: 


$$
\mathrm{TW}=\mathrm{NW} \times \mathrm{MF}
$$

Note:

TW : Total white blood cell

NW : number of white blood cells counted

MF : multiplier factor

$$
\mathrm{TE}=\mathrm{NE} \times \mathrm{MF}
$$

Note:

TE : Total eritrosit

NE : number of eritrosit counted

MF : multiplier factor

Observation of clinical symptoms on common carp begins when the fish has been infected by the A. hydrophila bacteria. Clinical symptoms observed damage to the body include ulcer inflammation, hemorrhage, wounds, exophthalmia, dropsy, response to feeding, and shocks.

Observation of survival rates was carried out from the first day of common carp infected by A. hydrophila until the last day of maintenance. Survival rates are observed by counting the number of fish that die every day. The percentage of survival rate was obtained using the Effendie (1997) method as follows.

$$
\mathrm{SR}=\frac{\mathrm{Nt}}{\mathrm{No}} \times 100
$$

Note:

$\mathrm{SR}=$ survival rate $(\%)$

$\mathrm{Nt}=$ the number of fish that live at the end of the research (fish)

No $=$ the number of fish that live at the beginning of the research (fish)

\section{Data analysis}

Data on leukocyte and erythrocyte levels, clinical symptoms, feeding response, response to shock, and survival rate of common carp were analyzed descriptively by comparing the treatments.

\section{Results}

Observation of the number of white blood cells was done to determine changes in the number of white blood cells in common carp before being treated, after being treated with lactic acid bacteria (LAB), and after being challenged with the Aeromonas hydrophila bacteria. Based on the observations of the number of white blood cells before being treated, post challenged, showed different numbers of white blood cells (Figure 1 and 2).

Figure 1 shows that all test fish soaked in a solution of lactic acid bacteria (LAB) isolates, ie treatment $\mathrm{B}, \mathrm{C}$ and $\mathrm{D}$ produced a higher number of white blood cells than controls (treatment A), which was around 125,00 $\mathrm{x} 10^{3}$ cells $\mathrm{mm}^{-3}-147,47 \times 10^{3}$ cells $\mathrm{mm}^{-3}$. The treatment of $\mathrm{D}(\mathrm{CcB} 15)$ resulted in the highest white blood cell count compared to other treatments.

Fish after challenged test with $A$. hydrophila $10^{8} \mathrm{CFU} \mathrm{mL}^{-1}$ showed varying numbers of white blood cells ranging from 144,80 $\mathrm{x} 10^{3}$ cells ml ${ }^{-3}$ to $154,70 \times 10^{3}$ cells $\mathrm{mm}^{-3}$ (Figure 2).

Tested fish soaked in LAB solution (treatment B, C, and D) experienced an increase in the number of white blood cells higher than the test fish that not soaked in LAB solution treatment A (control), which ranged between $17-38 \%$ (Table 1). This 


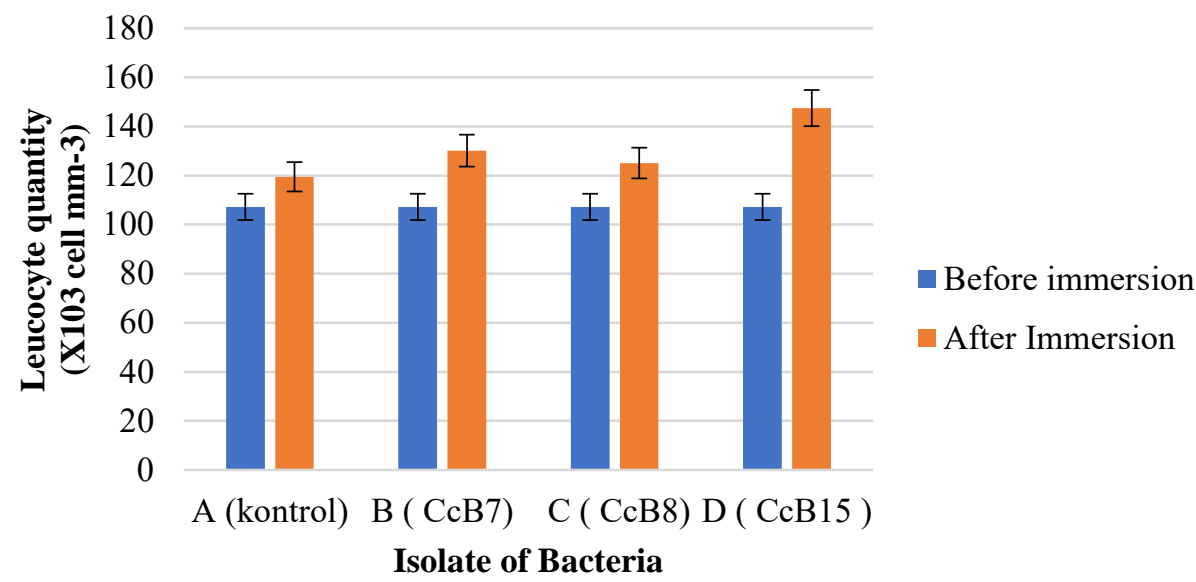

Figure 1 Amount of white blood cells after treatment

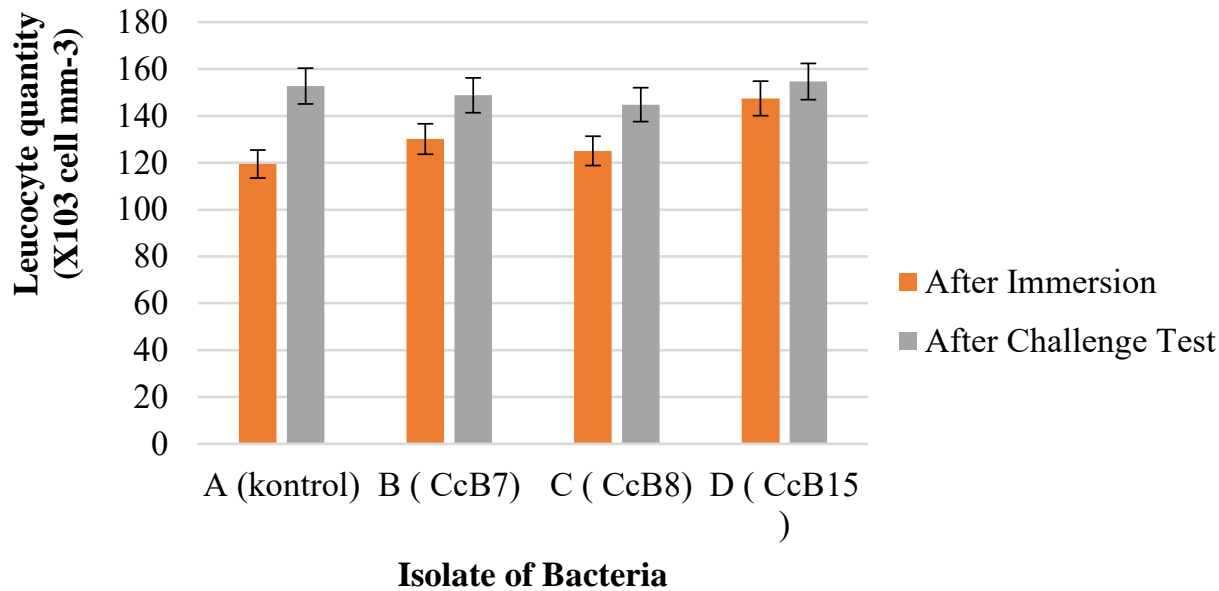

Figure 2 Amount of white blood cells after challenging test with Aeromonas hydrophila bacteria

proves that lactic acid bacteria have immunomodulatory activation, which plays an active role in enhancing the non-specific immune system of the fish body.

Table 2 shows that the test fish in treatment $\mathrm{A}$ experienced the highest increase in the number of white blood cells, which is $28 \%$. This indicates that the fish is still sick due to the attack of $A$. hydrophila. The onset of disease is caused by pathogenic bacteria having the ability to adhesion to the host so that it can produce colonization and cause disease.

Observation of clinical symptoms on common carp fingerling as test fish after infection with bacteria Aeromonas hydrophila with a density of $10^{8} \mathrm{cfu} \mathrm{mL}^{-1}$ includes damage to fish body, response to feeding, and shock. Fish body damage includes red stain (hyperami), necrosis, bleeding (hemoraghic), prominent eyes (exophthalmia) and bulging stomach (dropsy) (Table 3). 
Table 1 Average increase amount of white blood cells (leukocytes) of common carp after being treated with the BAL application

\begin{tabular}{cc}
\hline Treatment & Enhancement white blood cells (\%) \\
\hline A (control) & 11 \\
B (Cc B7) & 21 \\
C ( CcB8) & 17 \\
D (CcB15) & 38 \\
\hline
\end{tabular}

Table 2 Average Increase amount of white blood cells (leukocytes) of common carp after challenging test with Aeromonas hydrophila bacteria

\begin{tabular}{lc}
\hline Treatment & $\begin{array}{c}\text { Enhancement white blood cells } \\
(\%)\end{array}$ \\
\hline A (control) & 28 \\
B (CcB7) & 14 \\
C (CcB8) & 16 \\
D (CcB15) & 5 \\
\hline
\end{tabular}

Table 3 The damage of common carp body during challenging tests with Aeromonas hydrophila bacteria

\begin{tabular}{ccccccccccccc}
\hline $\begin{array}{c}\text { Observation } \\
\text { of the day }\end{array}$ & & \multicolumn{1}{c}{ Types of lactic acid bacterial isolates } \\
& 1 & 2 & 3 & 1 & 2 & 3 & 1 & 2 & 3 & 1 & 2 & 3 \\
\hline 1 & $\mathrm{a}$ & $\mathrm{a}$ & - & $\mathrm{a}$ & - & $\mathrm{a}$ & $\mathrm{a}$ & - & - & - & - & - \\
2 & $\mathrm{ac}$ & $\mathrm{ac}$ & $\mathrm{a}$ & $\mathrm{a}$ & $\mathrm{a}$ & $\mathrm{a}$ & $\mathrm{a}$ & - & $\mathrm{a}$ & - & - & $\mathrm{ac}$ \\
3 & $\mathrm{a}$ & $\mathrm{c}$ & $\mathrm{a}$ & $\mathrm{ac}$ & $\mathrm{a}$ & $\mathrm{ac}$ & $\mathrm{a}$ & $\mathrm{a}$ & $\mathrm{ac}$ & $\mathrm{a}$ & $\mathrm{a}$ & $\mathrm{c}$ \\
4 & $\mathrm{c}$ & $\mathrm{dc}$ & $\mathrm{a}$ & - & - & $\mathrm{c}$ & $\mathrm{ac}$ & - & $\mathrm{c}$ & $\mathrm{ac}$ & $\mathrm{c}$ & - \\
5 & $\mathrm{c}$ & $\mathrm{c}$ & $\mathrm{ac}$ & - & - & - & - & - & - & - & - & - \\
6 & $\mathrm{c}$ & $\mathrm{c}$ & $\mathrm{c}$ & - & - & - & - & - & - & - & - & - \\
7 & $\mathrm{c}$ & - & - & - & - & - & - & - & - & - & - & - \\
\hline
\end{tabular}

Note: a. Red Stain (hiperami) b. distended stomach (dropsy) c. Broken Fin d. Exophthalmic (-) There are no clinical symptoms

Observation of response to feed was carried out for seven days, observations carried out by looking at the response of the fish when fed and observing the remaining food that was deposited at the bottom of the aquarium. On day one after infecting most of the test fish in treatment A did not respond to the feed given, while the test fish in the treatment treated with lactic acid bacteria decreased response (Table 4).
Observation of responses to shocks or fish reflexes is carried out to determine fish health conditions for the presence of stimuli in the form of a shock to the movement of fish. In general, fish that have good health have sensitivity to disturbances in the form of good reflexes. Test response to shock is done by tapping the part of the aquarium wall for each treatment. 
Table 4 Response of common carp to feed after A. hydrophila $10^{8} \mathrm{CFU} \mathrm{mL}^{-1}$ bacterial infection

\begin{tabular}{ccccccccccccc}
\hline $\begin{array}{c}\text { Observa- } \\
\text { tion of the } \\
\text { day }\end{array}$ & & (A) & \multicolumn{10}{c}{ Cypes of lactic acid bacterial isolates } \\
\hline 1 & 1 & 2 & 3 & 1 & 2 & 3 & 1 & 2 & 3 & 1 & 2 & 3 \\
2 & - & - & + & + & + & + & + & + & + & + & + & + \\
3 & - & + & + & + & + & + & + & + & + & + & + & + \\
4 & - & + & + & + & + & + & + & ++ & + & + & + & ++ \\
5 & + & - & + & + & + & + & + & + & ++ & ++ & + & ++ \\
6 & + & + & + & ++ & + & + & ++ & ++ & ++ & ++ & ++ & ++ \\
7 & + & + & ++ & ++ & ++ & ++ & ++ & ++ & + & ++ & ++ & ++ \\
\hline & + & + & ++ & ++ & ++ & ++ & ++ & ++ & ++ & ++ & ++ & ++ \\
\hline
\end{tabular}

Note:

$(-)$ No response to feed

$(+)$ Response to low feed (there is leftover food)

$(++)$ Response to normal feed (feed is not left over)

Table 5 Response of common carp to shock after A. hydrophila $10^{8} \mathrm{CFU} \mathrm{mL}^{-1}$ bacterial infection

\begin{tabular}{ccccccccccccc}
\hline $\begin{array}{c}\text { Observation of the } \\
\text { day }\end{array}$ & \multicolumn{10}{c}{ (A) } & \multicolumn{10}{c}{ CcB7 (B) } & \multicolumn{1}{c}{ CcB8 (C) } & \multicolumn{3}{c}{ CcB15 (D) } \\
& 1 & 2 & 3 & 1 & 2 & 3 & 1 & 2 & 3 & 1 & 2 & 3 \\
\hline 1 & - & - & - & - & - & - & - & - & - & - & + & + \\
2 & - & - & + & + & + & + & - & + & + & + & + & + \\
3 & - & - & + & + & + & + & + & ++ & + & + & ++ & ++ \\
4 & - & + & + & + & ++ & ++ & + & ++ & ++ & ++ & + & ++ \\
5 & - & + & + & + & + & + & ++ & ++ & + & ++ & ++ & ++ \\
6 & + & + & + & ++ & ++ & ++ & ++ & + & ++ & ++ & ++ & ++ \\
7 & + & + & + & ++ & ++ & ++ & ++ & ++ & ++ & ++ & ++ & ++ \\
\hline
\end{tabular}

Note:

(-) No response to shock

(+) Response to low shock (there is leftover food)

$(++)$ Response to normal shock (feed is not left over)

Observation of the survival of common was carried out after the infection with $A$. hydrophila for seven days of maintenance. The observations showed that the various survival rates in each treatment ranged from $33.33 \%$ to $83.33 \%$ (Figure 5).

\section{Discussion}

Amount of white blood cells (leukocytes)

Based on observations of test fish in each treatment experienced a percentage increase in the number of white blood cells that differed after being treated with $\mathrm{LAB}$ solution (Table 1). Table 1 shows that test fish that were not soaked in LAB solution (control) experienced the lowest increase in white blood 


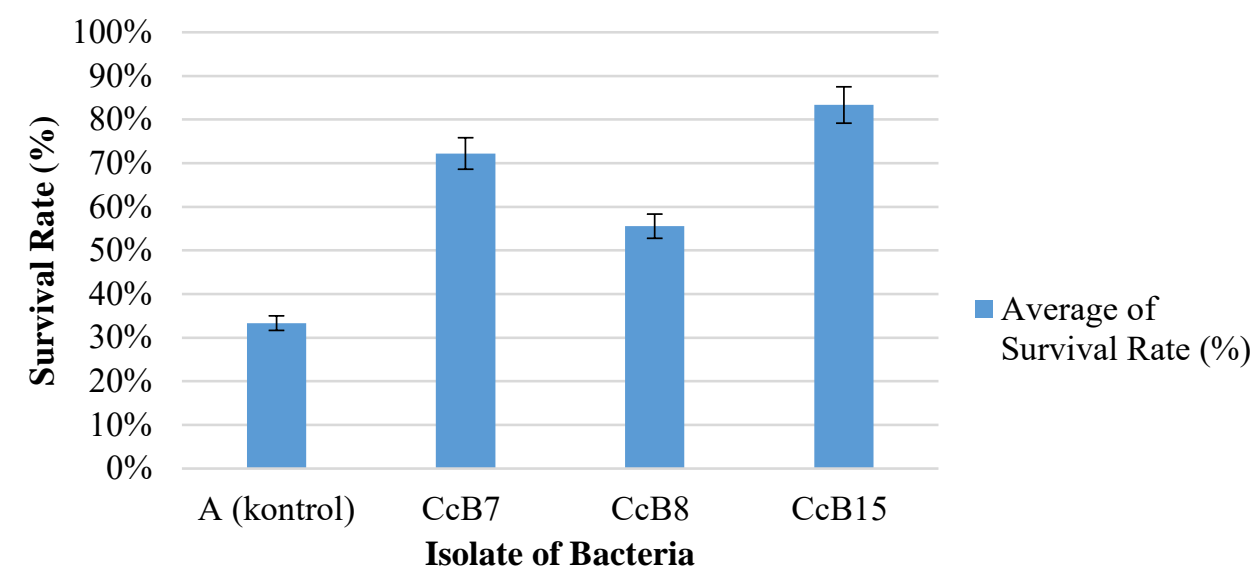

Figure 5 Survival rate of common carp after being challenged with $A$. hydropila $10^{8} \mathrm{CFU} \mathrm{mL}^{-}$ ${ }^{1}$ bacteria

cell count $(11 \%)$. The increase in the number of white blood cells in treatment A (control) occurs due to the increase in age and weight of the fish during the maintenance period. As the opinion of Claver \& Quaglia (2009) that age and weight of fish affect the fish's blood system, one of them is by increasing white blood cells. According to Takahashi \& Urbinati (2013), white blood cells are an indicator of innate immune (innate immune). Among natural immunostimulants, lactic acid bacteria (LAB) derived from the digestive tract of fish can replace antibiotics to control fish disease because of its role as a key in responding to fish immunity (Gómez et al. 2008). According to Whyte (2007), leukocytes are one of the blood cells that play a role in the innate immune system of the fish's body. Phagocytic activity is the body's defense mechanism and an essential characteristic of the immune system. According to Sekirov et al. (2010), the addition of microbial cells can induce gene expression in pathways associated with the immune system
Lactic acid bacteria that experienced the highest increase in white blood cell count were in treatment $\mathrm{D}(\mathrm{CcB} 15)$ was $38 \%$. Based on the results of the identification of the isolate BAL CcB15 strain, including Lactobacillus gasseri bacteria. According to Harikrishnan et al. (2010) \& Geng et al. (2012) among lactic acid bacteria (LAB) bacteria used as probiotics to improve fish growth, namely Lactobacillus spp and Lactococcus spp.

Figure 2 shows test fish in all treatments after being challenged to produce higher white blood cell counts than before challenge testing. This shows fish in conditions against pathogenic bacteria. Based on the observations of tested fish after being challenged, the percentage of white blood cells increased by different percentages (Table 2).

Tested fish given LAB isolates CcB15 (treatment D) resulted in a low increase in leucocyte levels was $5 \%$. The low increase in leucocyte levels in fish after challenge test showed fish in healthy condition. Lactic Acid Bacteria CcB15 isolates can inhibit the 
growth of pathogenic bacteria. This means that non-pathogenic bacteria are also bound to the same adhesion receptors as pathogenic strains so that pathogenic strains have no chance of adhesion, forming colonization and causing disease (Fooks \& Gibson 2002). Probiotics (non-pathogenic bacteria) seem to act as competitors (competitors) for pathogenic bacteria to bind themselves to adhesion receptors so that pathogenic bacteria cannot form colonies and thus cause disease.

According to Perez et al. (2007) mechanism of non-pathogenic bacteria, including $\mathrm{LAB}$ class in preventing several types of pathogenic bacterial infections through the release of bacteriokines (cytokine like molecules), $\mathrm{NO}$, free radicals, low $\mathrm{pH}$, receptor blocking, and inhibition of epithelial cell adhesion with the help of intestinal mucin (Djunaedi 2007). Several studies have also shown the ability of Lactobacillus species to stimulate IFN $\gamma$ production (interferon gamma) and IL-12 which further increases the body's resistance (Parvez et al. 2006).

According to Coconnier et al. (1993), pathogenic bacteria must have the ability to do adhesion to produce colonization and cause disease. There were many white blood cells in the treatment fish $\mathrm{A}, \mathrm{B}$, and $\mathrm{C}$ after challenge test due to phagocytosis in the fish's body. According to Dwinanti et al. (2014), the increase in white blood cells indicates that the fish is experiencing infection. The fish's body anticipates this condition by producing more white blood cells in response to immunity.
The workings of probiotic bacteria in urging the growth of disease-causing bacteria appear to begin with the effect of their work on the immune system. In the past decade, it was found that the lactobacilli eaten can stimulate macrophage activity against several different bacterial species. This may be caused by the absorption of antigen or lactobacilli translocation through the intestinal wall directly into the bloodstream to stimulate macrophages. The results of research conducted by volatile fatty acids Fooks \& Gibson (2002) produced by Lactic Acid Bacteria (LAB) were able to control the colonization of Shigella sonnei and Entero Pathogenic Echeriecia Coli (EPEC).

Clinical symptoms of common carp fingerling infected with Aeromonas hydrophila bacteria

Observation of clinical symptoms on common carp fingerling as test fish after infection with bacteria Aeromonas hydrophila with a density of $10^{8} \mathrm{cfu} \mathrm{mL}^{-1}$ includes damage to fish body, response to feed, and shock. Fish body damage includes red stain (hyperami), necrosis, bleeding (hemorrhagic), prominent eyes (exophthalmia), and bulging stomach (dropsy).

Based on Table 3, the treatment of A (control), B (CcB7) and $\mathrm{C}(\mathrm{CcB} 8)$ test fish, on day one after infection with $A$. hydrophila bacteria, body damage has begun to appear, 


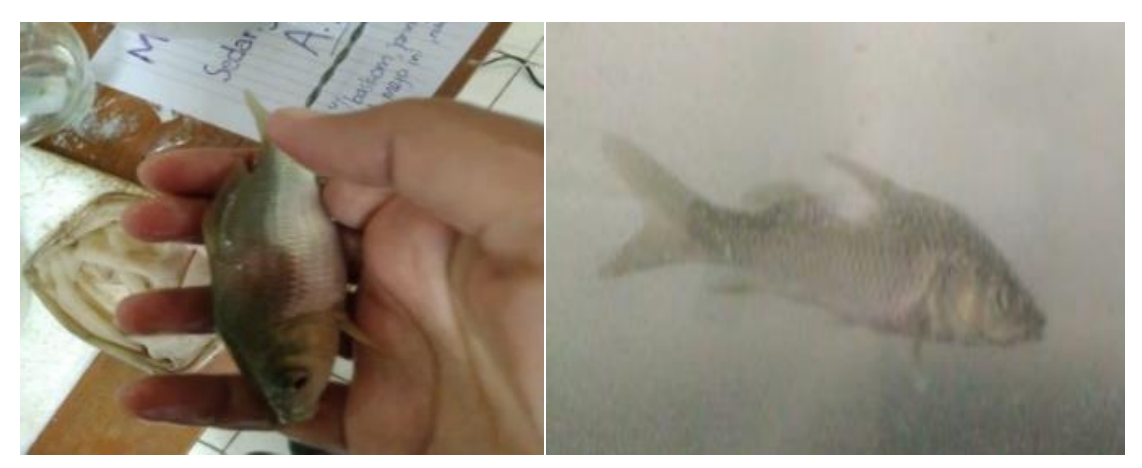

A

B

Figure 3 A Red stain (hyperemia), B. Flaky fin

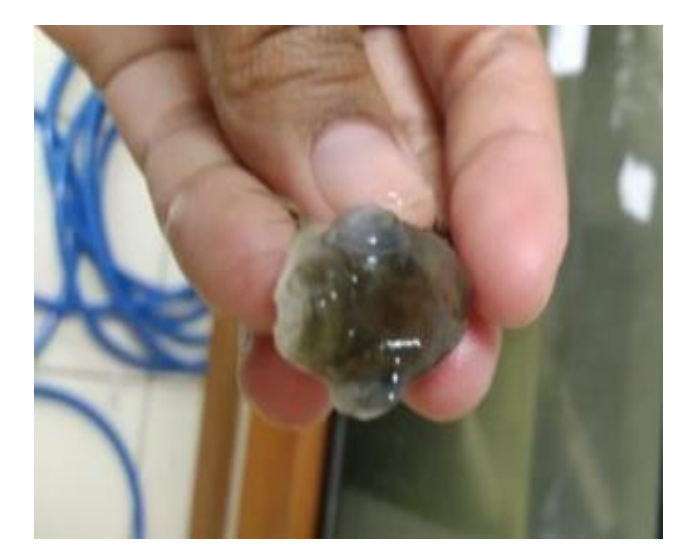

Figure 4 Fish experiencing Exophthalmia

although not in all test fish. The body damage seen was a red stain (hyperami) (Figure 3A). On the second day, the test fish in treatment D only had a small amount of damage to the body in the form of red stains and flaky fins (Figure 3B).

On day 4, the test fish in treatment A experienced exophthalmia marked with prominent eyes (Figure 4).

Clinical symptoms that appear after the fish is infected with Aeromonas hydrophila bacterium is in accordance with the statements of Lukistyowati et al. (2011), that clinical symptoms in common carp arising from A. hydrophilla bacterial infection, namely the onset of hyperemia, inflammation (necrosis and ulcers), especially in the injection site.

Tested fish in treatment B (CcB7) and C $(\mathrm{CcB} 8)$ and $\mathrm{D}(\mathrm{CcB} 15)$ starting on day 5 until the end of the observation there was no more damage to the body, clearly seen in the test fish in treatment D. This showed that the test fish in the treatment had high body resistance was seen from high levels of leucocyte after induced with probiotic $\mathrm{CcB} 15$ isolates (treatment D).

\section{Fish response to feed}

Table 4 shows that almost all goldfish in treatment A (control) on day one after the 
challenge test did not show a response to the feed given. This shows that fish in sick conditions due to the body's natural defenses cannot fight $A$. hydrophila attacks. According to Kabata (1985), fish infected with A. hydrophila bacteria cause a decrease in appetite.

In Treatment B (CcB7), C (CcB8) and D $(\mathrm{CcB} 15)$ have a better response to feed. This shows that A. hydrophila bacteria do not attack fish in healthy conditions. The natural defense of the fish's body has increased with the provision of lactic acid bacteria to be able to fight the attack of the bacteria. At the end of the observation the response of fish to feed returned to normal, indicating that fish are still in good health.

\section{Fish response to immersion test}

Tested fish in treatment A ( 0 ppm) on day one after infecting the response to shock did not exist. As well as fish that do not respond to the feed given, that fish is sick due to the attack of Aeromonas hydrophila bacteria. The natural immune system of fish is unable to fight the attack of the bacteria. Tested fish whose natural immune system has increased by giving lactic acid bacteria (LAB) at the end of the observation response to shock returns to normal, moves agile. Tested fish in treatment $\mathrm{D}$ recovery response to shock faster than other treatments, namely day 3 .

\section{Survival rate}

Figure 5 shows the A-treatment (control) test fish showed a low survival rate compared to the other treatment. This indicates that lactic acid bacteria (LAB) can increase the resistance of the common carp body, seen from higher leukocyte levels and mild body damage compared to controls. Lactic acid type Lactobacillus gasseri CcB15 strain is more potent in inducing the natural resistance of fish seen from elevated levels of leukocytes, mild clinical symptoms, recovery of response to feed, and a faster shock and the highest survival of $83.33 \%$. Leukocytes are cellular defenses that include non-specific defenses that will phagocyte pathogens, so mild clinical symptoms characterize the increase in fish body resistance.

\section{Conclusion}

Immersion carp (Cyprinus carpio $\mathrm{L}$ ) in a solution of lactic acid bacteria can increase the body's resistance to Aeromonas hydrophila bacteria, indicated by an increase in white blood cells by $21-38 \%$. Immersion of carp in lactic acid bacteria solution of CcB15 (Lactobacillus gasseri) isolate was most effective, as seen from the highest increase in white blood cell count (38\%), the mildest clinical symptoms, faster recovery, and the highest survival $(83.33 \%$.)

\section{References}

Abbas AK, Lichtman AH, Pillai S. 2010. Cellular and Molecular Immunology. Saunders Elsevier Philadelphia, PA, USA.

Claver JA, Quaglia AIE. 2009. Comparative morphology, development, and function of blood cells. Journal of Exotic Pet Medicine, 18: 87-97

Coconnier MH, Bernet MF, Chauviere G, Servin AL. 1993. Adhering heat-killed 
human lactobacillus acidophilus, strain $\mathrm{lb}$, inhibits the process of pathogenicity of diarrhoeagenic bacteria in cultured human intestinal cells. Journal of Diarrhoeal Diseases Research. 11(4): 235242

Djunaedi D. 2007. Effect of probiotics on immune response. Jurnal Kedokteran Brawijaya, 13(1): 22-27.

Dwinanti SH, Sukenda, Yuhana M, Lusiastuti AM. 2014. Toxicity and immunogenicity of extracellular products of non-hemolytic Streptococcus agactiae in tilapia (Oreochromis niloticus). Jurnal Akuakultur Rawa Indonesia, 2(1): 105116.

Effendie MI. 1997. Biologi Perikanan. Yayasan Pustaka Nusatama. Yogyakarta. 163 halaman

Fooks LJ, Gibson GR. 2002. Probiotics as modulators of the gut flora. British Journal of Nutrition, 88(1): 39-49

Geng X, Dong XH, Tan, BP, Yang HQ, Chi YH, Liu, Y. 2012. Effects of dietary probiotic on the growth performance, non specific immunity and disease resistance of cobia, Rahycentron canadum. Aquaculture Nutrition, 18(1): 46-55.

Giri SS, Sukumaran V, Dangi NK. 2012. Characteristics of bacterial isolates from the gut of freshwater fish Labeo rohita that may be useful as potential probiotic bacteria. Probiotics Antimicro, 4 : 238242.

Gómez GD, Balcázar JL. 2008. A review on the interactions between gut microbiota and innate immunity of fish. FEMS Immunology and Medical Microbiology, 52(2): 145-154.

Hardi EH, Pebrianto CA. 2012. Isolation and postulant test of koch Aeromonas sp. and Pseudomonas sp. on tilapia (Oreochromis niloticus) at the Center of Loa Kulu Cultivation in Kutai Kartanegara Regency. Jurnal Ilmu Perikanan Tropis, 16(2): 35- 39.
Harikrishnan R. Balasundaram C, Heo MS. 2010. Lactobacillus sakei BK19 enriched diet enhances the immunity status and disease resistance to streptococcosis infection in kelp grouper, Epinephelus bruneus. Fish Shellfish Immunology, 29(6): 1037-1043.

Kabata Z.1985. Parasites and Diseases of Fish Cultured in Tropics. Taylor and Francis Ltd. London UK. 318 pp

Kaleeswaran B, Ilavenil S, Ravikumar S. 2011. Dietary suplementation with Cynodon dactylon L. Enhances innate immunity and disease resistance of Indian major carp, Catla catla (Ham). Fish Shellfish Immunology, 31(6): 953 962.

Lipsitch M. 2001. The rice and fall of antimicrobial resistance. Trends Microbiology, 9: 438-444

Lukistyowati, Iesje dan Kurniasih. 2011. Kelangsungan hidup ikan mas (Cyprinus carpio) yang diberi pakan ekstrak bawang putih (Alluim sativum) dan diinfeksi Aeromonas hydrophila. Jurnal Perikanan dan Kelautan, 3(1): 144-160

Ministry of Marine Affairs and Fisheries. 2016. KPDA. Pusat Data dan Statistik. Kementerian Kelautan dan Perikanan. $112 \mathrm{p}$

Parvez S, Malik KA, Kang SA, Kim HY. 2006. Probiotics and their fermented food products are beneficial for health. Journal of Applied Microbiology 100: 1171-1185

Patriono E, Junaidi E, Setiorini A. 2009. Pengaruh pemotongan sirip terhadap pertumbuhan panjang tubuh ikan mas (Cyprinus carpio). Penelitian Sains Unsriwijaya, 9: 12-13

Perez-Morales R., Iniguez-Palomares, C., Acedo-Felix E. 2007. Evaluation of probiotic properties in Lactobacillus isolated from small intestine of piglets. $R e$ vista Latino Americana de Microbiologia . 49(3-4): 46-54. 
Rawung M.E. dan H. Manoppo, 2014. The use of baker's yeast (Saccharomyces cereviciae) in situ to improve the response of non-specific immune to tilapia (Oreochromis niloticus). Jurnal Budidaya Perairan. 2(2): 7-14

Rosidah, Junianto, Lili W, Maulidya, B. 2018. Effectivity of sambiloto extract as medicine for catfish (Pangasius hypophthalmus) juveniles infected by Aeromonas hydrophila. International Journal of Fisheries and Aquatic Studies. 5(6): 236-241

Sahoo PK, Rauta PR, Mohanty BR, Mohapatra KD, Saha JN, Rye, M. 2011. Selection of improved resistanceto Aeromonas hydrophyla in India major carp Labeo rohita: Survival and innate immune responses in first generation of resistant and susceptible lines Fish Shellfish Immunology. 31(3): 432-438.

Sekirov I, Russell SL, Atunes LCM, Finlay BB. 2010. Gut microbiota in health and disease.Physiological Reviews. 90: 859904.

Septiarini, Harpeni E, Wardiyanto. 2012. Effect of different probiotic giving time on non-specific immune response on common carp (Cyprinus carpio L.) tested for Aeromonas salmonicida Bacteria. Jurnal Rekayasa dan Teknoogi Budidaya Perairan. 1 (1): 58-64

Sharifuzzaman SM, Abbas A, Tinley JW, Austin B, 2011. Subcellular components of probiotic Kocuria SM1and Rhodococcus SM2 induce protective immunity in rainbow trout Oncorhynchus mykiss (Walbaum) against Vibrio anguillarum. Fish Shellfish Immunology, 30: 347-353.

Sugita H, Hirose Y, Matsuo N, Deguchi Y. 1998. Production of the antibacterial substance by Bacillus sp. strain NM 12, an intestinal bacterium of Japanese coastal fish. Aquaculture, 165 (3-4): 269-280.

Takahashi JDB, Urbinati EC. 2013. Fish immunology. The modification and manipulation of the innate immune system: Brazilian Studies. Annals of the Brazilian Academy of Sciences, 86(3): 14831495

Whyte SK. 2007. The innate immune response of finfish - a review of current knowledge. Fish \& Shellfish Immunology. 23(6): 1127-1151 